\title{
Cutaneous Collagenous Vasculopathy: A Rare Form of Microangiopathy Successfully Treated with a Combination of Multiplex Laser and Optimized Pulsed Light with a Review of the Literature
}

\author{
Davide Basso $^{\mathrm{a}, \mathrm{c}}$ Simone Ribero ${ }^{\mathrm{a}, \mathrm{d}} \quad$ Claudia Blazek $^{\mathrm{a}}$ Nathalie Dietrich $^{\mathrm{a}}$ \\ Helmut Beltraminelli ${ }^{a} \quad$ Albert A. Ramelet $^{a} \quad$ Luca Borradori $^{a}$ Maurice Adatto ${ }^{a, b}$ \\ ${ }^{a}$ Department of Dermatology, University Hospital Inselspital Bern, University of Bern, Bern, and \\ bSkinpulse Dermatology, Laser and Beauty Centers, Geneva, Switzerland; 'Section of Dermatology, \\ University of Genoa, Genoa, and d Section of Dermatology, Department of Medical Sciences, \\ University of Turin, Turin, Italy
}

\section{Key Words}

Cutaneous collagenous vasculopathy .

Multiplex laser · Optimized pulsed light

\begin{abstract}
Cutaneous collagenous vasculopathy (CCV) is a rare idiopathic microangiopathy of the cutaneous vasculature characterized histologically by the presence of dilated small blood vessels with flat endothelial cells and thickened walls containing hyaline material in the upper dermis. We report an elderly patient presenting with an extensive form of CCV involving the trunk, upper and lower limbs. She was treated with Multiplex PDL 595-nm/Nd:YAG 1,064-nm laser and optimized pulsed light. This approach, which has never been reported for CCV so far, resulted in a striking and almost complete clearance of the widespread lesions. We here review our knowledge about CCV and therapeutic options available with a survey of the literature.

(c) 2015 S. Karger AG, Basel
\end{abstract}

\section{Introduction}

Cutaneous collagenous vasculopathy $(\mathrm{CCV})$ is a rare microangiopathy of unknown origin, which involves the superficial cutaneous vasculature [1]. CCV typically develops in middle-aged patients with cutaneous telangiectasia on the trunk, lower and upper limbs. Cutaneous lesions are usually asymptomatic but sometimes disfiguring. The perivascular fibrosis is thought to be due to the production of abnormal collagen by veil cells in the outer vessel walls as a result of unknown factors [1]. Although there is no cure for this usually chronic and progressive condition, vascular laser should be considered to significantly improve both skin lesions and the quality of life of affected patients. These were successfully treated for the first time with an optimized pulsed light (OPL) combined with a multiplex sequential PDL 595-nm/Nd:YAG 1,064-nm laser, and we review previous cases of $\mathrm{CCV}$ and available therapeutic options.

\section{Case Report}

A 77-year-old woman was evaluated for generalized asymptomatic telangiectasias (fig. 1a). The lesions had first developed by the age of 20 years on the lower legs and subsequently spread onto the thighs, arms and chest. The family history was unremarkable. The medical history revealed surgery for ovarian cystic adenocarcinoma, ischemic heart disease with arrhythmias and chronic renal insufficiency with generalized itch. The patient was on phenprocoumon, acetylsalicylic acid, oxazepam and levocetirizine.

Physical examination showed widespread telangiectasias distributed symmetrically on the legs, arms and chest. Some lesions were raised, slightly hypertrophic

D.B., S.R., L.B. and M.A. contributed equally.

\section{KARGER}

E-Mail karger@karger.com

www.karger.com/drm
(C) 2015 S. Karger AG, Base

$1018-8665 / 15 / 2321-0107 \$ 39.50 / 0$
Simone Ribero, MD, $\mathrm{PhD}$

Section of Dermatology

Department of Medical Sciences, University of Turin

Via Cherasco 23, IT-10100 Torino (Italy)

E-Mail simone.ribero@unito.it 

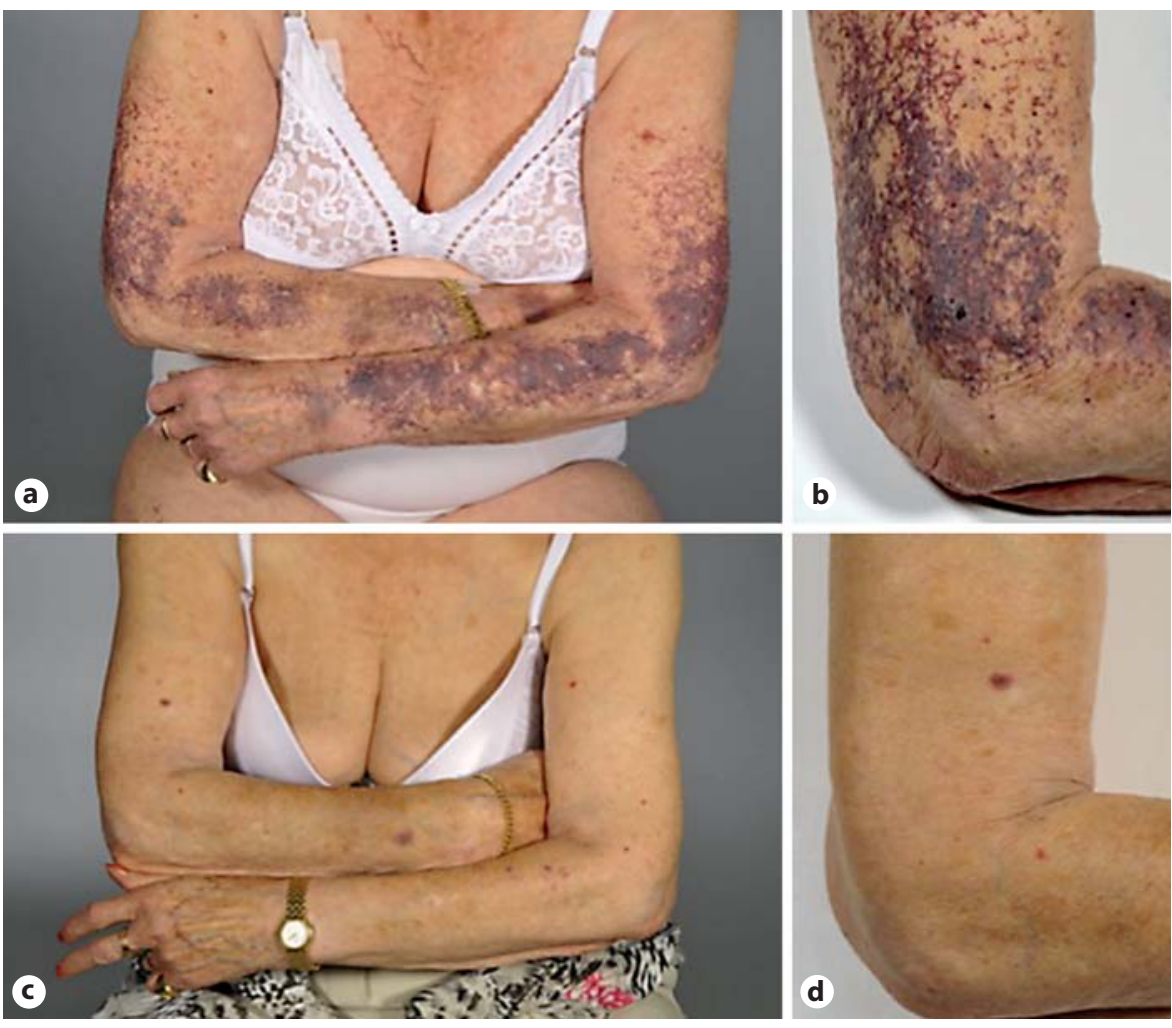

Fig. 1. a Diffuse acquired telangiectasias over the arms and chest. b Close-up view of the right arm. c Postintervention resolution of the telangiectasias over the arms and the chest. d Postintervention close-up view of the right arm.
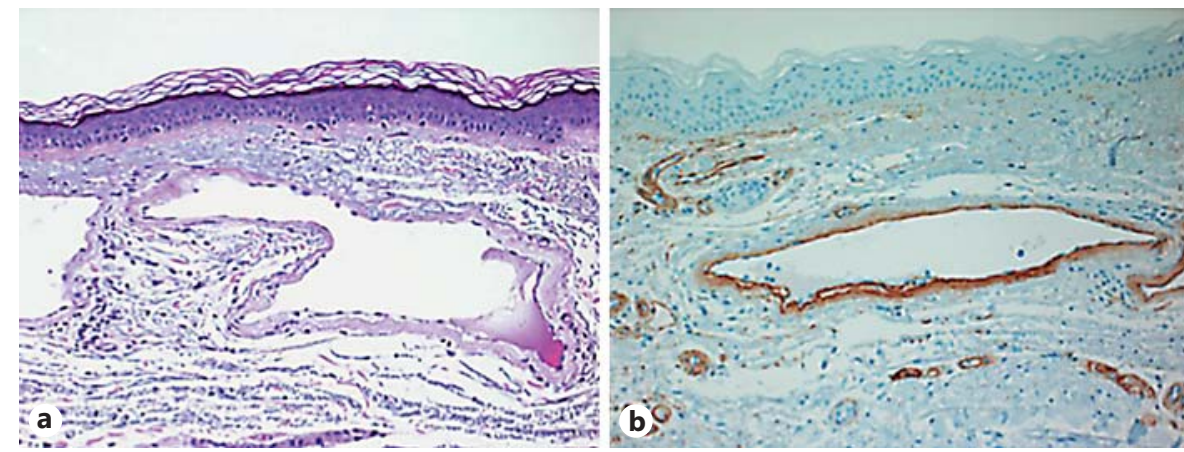

Fig. 2. a Telangiectasia of dermal capillaries with hyalinized thickening of the vessel wall. b The hyaline material within the thick vessel wall is positive for collagen type IV.

and more of a purple color, while some others were completely flat and bright red. There was no mucosal or nail involvement.

Light microscopy studies of a biopsy specimen obtained from the leg revealed dilated superficial cutaneous vessels with perivascular deposits of hyaline material (fig. 2a). A staining with collagen type
IV was visible at immunohistochemistry (fig. 2b).

The patient desired to improve the disturbing cosmetic appearance of these extensive red-blue lesions, especially on the arms and forearms. We proposed laser treatment using a combination of a Multiplex PDL 595-nm/Nd:YAG 1,064-nm laser as well as an OPL. The following parameters were used, as spot tests first, with the laser, on the hypertrophic lesions: 595-nm pulsed dye laser, a $7-\mathrm{mm}$ spot at $8.5 \mathrm{~J} / \mathrm{cm}^{2}$ and a $10-\mathrm{ms}$ pulse duration followed sequentially by a $500-\mathrm{ms}$ interval, then a pulse of 1,064-nm Nd:YAG laser at $55 \mathrm{~J} /$ $\mathrm{cm}^{2}$ and a $15-\mathrm{ms}$ pulse duration (Cynergy Multiplex, Cynosure, Westford, Mass., USA). This was delivered in a single pass with no overlap. Forced chilled air was used for parallel cooling. For flat lesions, we used an OPL (Limelight Cutera, Brisbane, Calif., USA) with a 520-nm filter, a $10 \times 30 \mathrm{~mm}$ spot, fluence range of $16-18$ $\mathrm{J} / \mathrm{cm}^{2}, 8-9 \mathrm{~ms}$ of pulse width, with contact cooling and 2 perpendicular passes. The response of these tests gave a remarkable improvement. Therefore all lesions of the upper limbs and trunk were subsequently treated using the same parameters. Almost complete clearance of the telangiectasia on both arms and the chest was obtained after a total of 7 combined laser/intense pulsed light treatment sessions, performed every 4-8 weeks (fig. 1b).

\section{Discussion}

Our patient had clinical and histopathological features typically described as $\mathrm{CCV}$, a distinctive primary cutaneous microangiopathy first described in $2000[1,2]$. This entity is rare since only 25 cases have been described so far in the English literature (table 1).

CCV has almost exclusively been reported in middle-aged subjects [3], even though 1 pediatric case has been reported [4]. In our patient, cutaneous telangiectasia originally developed on the lower legs and progressed subsequently to the thighs, trunk and the upper extremities in accordance with data reported in the literature [5]. Usually lesions are almost invariably asymptomatic although some itching may occur [5]. Lesions remain then relatively stable or may occasionally worsen during the summer months [2]. No mucosal involvement has been reported so far.

Light microscopy studies are essential for the diagnosis of CCV. This typically shows dilated small blood vessels in the superficial dermis and, more rarely, in the midreticular dermis. Sparse lymphocytes scattered around the vessel walls may be found. Electron microscopy studies disclose dilated postcapillary venules with flat endothelial cells and a thickened laminat- 
Table 1. Survey of the literature: cases of CCV and their management

\begin{tabular}{|c|c|c|c|c|c|c|c|c|}
\hline No. & Authors & $\begin{array}{l}\text { Age, } \\
\text { years }\end{array}$ & Sex & Race & Medical history & Distribution & Evolution & Treatment \\
\hline 1 & $\begin{array}{l}\text { Salama and } \\
\text { Rosenthal }[1] \\
2000\end{array}$ & 54 & M & Caucasian & Depression & $\begin{array}{l}\text { Trunk, upper and lower } \\
\text { limbs }\end{array}$ & 5 years & No \\
\hline \multirow[t]{3}{*}{2} & \multirow[t]{3}{*}{$\begin{array}{l}\text { Davis et al. [6], } \\
2008\end{array}$} & 59 & M & Caucasian & $\begin{array}{l}\text { Diabetes mellitus, hypercholesterolemia, } \\
\text { hypertension }\end{array}$ & Forearm, chest, abdomen & 7 months & No \\
\hline & & 6 & $\mathrm{M}$ & Caucasian & Diabetes mellitus, hypertension, psoriasis & Thigh & Unclear & No \\
\hline & & 80 & $\mathrm{M}$ & Caucasian & $\begin{array}{l}\text { Atrial fibrillation, gastroesophageal reflux, venous } \\
\text { insufficiency }\end{array}$ & $\begin{array}{l}\text { Abdomen, thigh, back, } \\
\text { hands }\end{array}$ & Unclear & No \\
\hline 3 & $\begin{array}{l}\text { Kanitakis et al. } \\
{[8], 2010}\end{array}$ & 65 & M & Caucasian & $\begin{array}{l}\text { Hypertension, coronary infarction, prostatic } \\
\text { adenoma }\end{array}$ & $\begin{array}{l}\text { Lower extremities, } \\
\text { abdomen, buttocks, back }\end{array}$ & $5-6$ years & No \\
\hline 4 & $\begin{array}{l}\text { Monteagudo } \\
\text { et al. [11], } 2010\end{array}$ & 68 & M & Caucasian & $\begin{array}{l}\text { Hypertension, hypercholesterolemia, prostatic } \\
\text { adenoma, hyperuricemia }\end{array}$ & $\begin{array}{l}\text { Forearm, abdomen, } \\
\text { lower limbs }\end{array}$ & 15 years & No \\
\hline \multirow[t]{2}{*}{5} & \multirow[t]{2}{*}{$\begin{array}{l}\text { Perez et al. [7], } \\
2010\end{array}$} & 51 & $\mathrm{~F}$ & Caucasian & Hypothyroidism, psoriasis & $\begin{array}{l}\text { Trunk, neck, upper } \\
\text { and lower limbs, } \\
\text { retroauricular area }\end{array}$ & 16 years & No \\
\hline & & 71 & $\mathrm{~F}$ & Caucasian & Pituitary tumor, osteoporosis & $\begin{array}{l}\text { Feet, knees, upper limbs, } \\
\text { chest, cheeks }\end{array}$ & 7 years & No \\
\hline 6 & $\begin{array}{l}\text { Lloyd et al. [4], } \\
2011\end{array}$ & 16 & $\mathrm{~F}$ & Caucasian & Mood disorders & Trunk, legs & 3 years & No \\
\hline \multirow[t]{2}{*}{7} & \multirow{2}{*}{$\begin{array}{l}\text { González } \\
\text { Fernández } \\
\text { et al. [3], } 2012\end{array}$} & 83 & $\mathrm{~F}$ & Caucasian & $\begin{array}{l}\text { Atrial fibrillation, mitral valve disease, hepatitis C, } \\
\text { hypertension }\end{array}$ & $\begin{array}{l}\text { Upper and lower limbs, } \\
\text { abdomen }\end{array}$ & $>20$ years & No \\
\hline & & 74 & $\mathrm{~F}$ & Caucasian & Discoid lupus, venous insufficiency & Lower limbs & & No \\
\hline 8 & $\begin{array}{l}\text { Echeverría } \\
\text { et al. [14], } 2012\end{array}$ & 42 & $\mathrm{~F}$ & Caucasian & - & $\begin{array}{l}\text { Upper and lower limbs, } \\
\text { abdomen }\end{array}$ & 7 years & $\begin{array}{l}\text { PDL, } \\
\text { successful }\end{array}$ \\
\hline \multirow[t]{4}{*}{9} & \multirow[t]{4}{*}{$\begin{array}{l}\text { Burdick et al. } \\
{[2], 2012}\end{array}$} & 68 & M & Unknown & $\begin{array}{l}\text { Macular degeneration since childhood, } \\
\text { hypertension, hyperlipidemia, gastroesophageal } \\
\text { reflux disease }\end{array}$ & Legs, abdomen & Several weeks & No \\
\hline & & 59 & M & Unknown & $\begin{array}{l}\text { Diabetes mellitus, hypertension, hyperlipidemia, } \\
\text { osteoarthritis, depression }\end{array}$ & Arms, legs & $\begin{array}{l}\text { Several } \\
\text { months }\end{array}$ & No \\
\hline & & 70 & $\mathrm{M}$ & Unknown & $\begin{array}{l}\text { Hypertension, diabetes mellitus, } \\
\text { hypercholesterolemia }\end{array}$ & Right leg & 10 years & No \\
\hline & & 41 & $\mathrm{~F}$ & Unknown & Basal cell carcinoma, inactive hepatitis & Arms & Several years & No \\
\hline 10 & $\begin{array}{l}\text { Bernard et al. } \\
{[21], 2012}\end{array}$ & 47 & $\mathrm{~F}$ & Unknown & $\begin{array}{l}\text { Diabetes mellitus type } 1 \text {, psoriasis, hypertension, } \\
\text { hypothyroidism }\end{array}$ & Lower limbs, abdomen & $1-2$ years & No \\
\hline 11 & $\begin{array}{l}\text { Salama et al. [5], } \\
2014\end{array}$ & 84 & M & Caucasian & $\begin{array}{l}\text { Myelodysplastic syndrome, diabetes mellitus, celiac } \\
\text { disease, tuberculosis, tachycardia }\end{array}$ & Lower limbs and trunk & 3 years & No \\
\hline \multirow[t]{7}{*}{12} & \multirow[t]{7}{*}{$\begin{array}{l}\text { Salama [22], } \\
2015\end{array}$} & 68 & $\mathrm{~F}$ & Unknown & $\begin{array}{l}\text { Mild chronic renal failure, } \\
\text { cryofibrinogenemia }\end{array}$ & Lower limbs & Unknown & - \\
\hline & & 85 & $\mathrm{~F}$ & Unknown & Diabetes mellitus & Lower limbs & 10 years & No \\
\hline & & 50 & $\mathrm{~F}$ & Unknown & - & $\begin{array}{l}\text { Lower limbs and upper } \\
\text { limbs }\end{array}$ & 2 years & No \\
\hline & & 69 & $\mathrm{~F}$ & Unknown & Diabetes mellitus & $\begin{array}{l}\text { Lower limbs and upper } \\
\text { limbs, abdomen }\end{array}$ & Unknown & No \\
\hline & & 56 & $\mathrm{~F}$ & Unknown & - & $\begin{array}{l}\text { Lower limbs and upper } \\
\text { limbs, trunk }\end{array}$ & 25 years & No \\
\hline & & 42 & $\mathrm{~F}$ & Unknown & Raynaud phenomenon & Lower limbs & $>20$ years & No \\
\hline & & 73 & M & Unknown & - & $\begin{array}{l}\text { Lower limbs and upper } \\
\text { limbs }\end{array}$ & 2.5 years & No \\
\hline 13 & $\begin{array}{l}\text { Bardazzi et al. } \\
{[23], 2014}\end{array}$ & 57 & $\mathrm{~F}$ & Caucasian & Uveitis, hypertension & $\begin{array}{l}\text { Legs, abdomen, buttocks, } \\
\text { hips, trunk, arms, malar } \\
\text { region, fingers }\end{array}$ & 9 years & No \\
\hline 14 & $\begin{array}{l}\text { This study, } \\
2015\end{array}$ & 77 & $\mathrm{~F}$ & Caucasian & $\begin{array}{l}\text { Renal insufficiency, venous insufficiency, ovarian } \\
\text { adenocarcinoma, ischemic heart disease }\end{array}$ & $\begin{array}{l}\text { Upper and lower limbs, } \\
\text { chest }\end{array}$ & $>20$ years & $\begin{array}{l}\text { PDL/ } \\
\text { Nd:YAG }\end{array}$ \\
\hline
\end{tabular}


ed basement membrane consisting of an amorphous eosinophilic hyaline material $[2,3]$. By immunohistochemistry, vascular cells of endothelial origin are CD31 and CD34 positive. The amorphous eosinophilic hyaline material is stained using antibodies directed against laminins, fibronectin and, characteristically, type IV collagen [5-7]. No amyloid deposits by Congo red staining are found.

CCV has to be differentiated from a number of other vascular disorders presenting with cutaneous telangiectasias, including benign hereditary telangiectasia, angioma serpiginosum and telangiectasia macularis eruptiva perstans [3]. Generalized essential telangiectasia (GET) [8] is another benign condition that should be differentiated from CCV. At variance with $\mathrm{CCV}, \mathrm{GET}$ is more common in women and can rarely also involve the oral mucosa and conjunctiva. In contrast to CCV, in GET there are dilated vessel walls, which consist of thickened endothelial cells, but without any deposition of amorphous hyaline material $[2,9]$.

The question remains whether the peculiar histopathological findings of CCV are sufficient to distinguish CCV from GET as a distinct disease or whether both conditions represent different faces of a single disease. We included in the study only the certified CCV.

The mechanisms leading to the development of CCV remain unknown. Some authors have discussed a nonimmunologically related injury of the endothelial cells by unknown factors, which ultimately lead to the production of abnormal collagen and reparative fibrosis [4]. The intake of drugs, encompassing corticosteroids, lithium, tiotixene, interferon, isotretinoin, calcium channel blockers, antibiotics or antidepressants, has been thought to act as trigger $[7,10]$.

Conditions such as diabetes mellitus or hypertension may further contribute. Most likely CCV represents a response pattern triggered by multiple factors $[2,3,11]$.

The therapy of CCV is challenging. If the patient wants a cosmetic improvement, lasers and other light sources represent the first therapeutic option. The latter are working according to the principle of selective photothermolysis [12]. When treating vascular lesions, the primary target is oxyhemoglobin [13]. Two cases of CCV have been treated by a pulsed dye laser [14]. We opted for a combination of Multiplex PDL/ YAG laser on thicker, purple lesions, together with an OPL on the flatter, redder ones. The advantages of this combination of energy-based devices during the same session are: (a) the Multiplex laser, which combines PDL at $595 \mathrm{~nm}$ followed by YAG at $1,064 \mathrm{~nm}$, is ideal for treating hypertrophic vascular lesions; this specific device has already been used successfully in treating various vascular conditions, with better vessel clearance than with a single pulsed laser [15]; (b) the OPL is an evolution of the intense pulsed light, developed in 1992 [16], as it brings true square pulse emission. This peculiarity gives a very precise control of delivered fluencies, similar to a laser, even being a noncoherent light source. Our OPL, due to its large spot size $(10 \times 30 \mathrm{~mm})$ allowed speed, comfort and also very good cosmetic results in treating large areas when compared with a laser with a small spot size $(7-10 \mathrm{~mm})$. A few cases of essential telangiectasias have been published using an intense pulsed light [17-20]. To our knowledge, our case is the first describing a case of CCV successfully treated with an OPL combined with a Multiplex laser within the same session.

In conclusion, we here describe the first successful case of CCV treated with an OPL combined with a multiplex sequential PDL 595-nm/Nd:YAG 1,064-nm laser within the same session. This approach led to an impressive aesthetical improvement despite the very large affected surface. Even if a causal treatment of this difficult skin disease has not already been discovered, the combination approach used here seems very effective.

\section{Acknowledgment}

The authors kindly acknowledge the support of Dr. Nathalie Irla and Dr. Ivan Hegyi for their help in the evaluation of the patient.

\section{Disclosure Statement}

The authors have no conflicts of interest to disclose.

\section{References}

1 Salama S, Rosenthal D: Cutaneous collagenous vasculopathy with generalized telangiectasia: an immunohistochemical and ultrastructural study. J Cutan Pathol 2000;27: 40-48.

-2 Burdick LM, Losher S, Somach SC, et al: Cutaneous collagenous vasculopathy: a rare cutaneous microangiopathy. J Cutan Pathol 2012;39:741-746.

-3 González Fernández D, Gómez Bernal S, et al: Cutaneous collagenous vasculopathy: description of two new cases in elderly women and review of the literature. Dermatology 2012;225:1-8

4 Lloyd BM, Pruden SJ 2nd, Lind AC, et al: Cutaneous collagenous vasculopathy: report of the first pediatric case. Pediatr Dermatol 2011;28:598.
-5 Salama S, Chorneyko K, Belovic B: Cutaneous collagenous vasculopathy associated with intravascular occlusive fibrin thrombi. J Cutan Pathol 2014;41:386-393.

$\checkmark 6$ Davis TL, Mandal RV, Bevona C, et al: Collagenous vasculopathy: a report of three cases. J Cutan Pathol 2008;35:967.

7 Perez A, Wain ME, Robson A, et al: Cutaneous collagenous vasculopathy with generalized telangiectasia in two female patients. J Am Acad Dermatol 2010;63:882.

$>8$ Kanitakis J, Faisant M, Wagschal D, et al: Cutaneous collagenous vasculopathy: ultrastructural and immunohistochemical study of a new case. Am J Clin Dermatol 2010;11:63.

9 Becket SW: Generalized telangiectasia: clinical study with special consideration of the etiology and pathology. Arch Dermatol 1926; 14:387-426.
10 Requena L, Sangueza OP: Cutaneous vascular anomalies. II. Hamartomas, malformation and dilatation of preexisting vessels. J Am Acad Dermatol 1997;37:523-549.

11 Monteagudo B, Perez-Valcarcel J, RamirezSantos A, et al: Cutaneous collagenous vasculopathy: a case report and review of the literature. Actas Dermosifiliogr 2010;101:444.

12 Anderson RR, Parrish JA: Selective photothermolysis: precise microsurgery by selective absorption of pulsed radiation. Science 1983; 220:524-527.

13 Baumler W, Vural E, Landthaler M, et al: The effects of intense pulsed light (IPL) on blood vessels investigated by mathematical modeling. Lasers Surg Med 2007;39:132-139.
Basso/Ribero/Blazek/Dietrich/ Beltraminelli/Ramelet/Borradori/Adatto 
14 Echeverría B, Sanmartín O, Botella-Estrada R, et al: Cutaneous collagenous vasculopathy successfully treated with pulsed dye laser. Int J Dermatol 2012;51:1359-1362.

15 Li G, Sun J, Shao X, et al: The effects of 595and 1,064-nm lasers on rooster comb blood vessels using dual-wavelength and multipulse techniques. Dermatol Surg 2011;37:14731479.

16 Wat H, Wu DC, Rao J, et al: Application of intense pulsed light in the treatment of dermatologic disease: a systematic review. Dermatol Surg 2014;40:359-377.
7 Babilas P, Schreml S, Szeimies RM, et al: Intense pulsed light (IPL): a review. Lasers Surg Med 2010;42:93-104.

18 Fernández-Torres R, del Pozo J, de la Torre C, et al: Generalized essential telangiectasia: a report of three cases treated using an intense pulsed light system. Actas Dermosifiliogr 2010;101:192-193.

19 Raulin C, Weiss RA, Schönermark MP: Treatment of essential telangiectasias with an intense pulsed light source (PhotoDerm VL). Dermatol Surg 1997;23:941-945.

20 Wenzel SM, Hohenleutner U, Landthaler M: Progressive disseminated essential telangiectasia and erythrosis interfollicularis colli as examples for successful treatment with a high-intensity flashlamp. Dermatology 2008; 217:286-290
21 Bernard S, Cawet B, Theate Y, et al: Cutaneous collagenous vasculopathy: a rare cause of generalized telangiectasia. Ann Dermatol Venereol 2012;139:381-386.

22 Salama SS: Cutaneous collagenous vasculopathy: a new case series with clinicopathologic and ultrastructural correlation, literature review, and insight into the pathogenesis. Am J Dermatopathol 2015;37:368-375.

23 Bardazzi F, Virdi A, Odorici G, et al: Cutaneous collagenous vasculopathy: report of a case. Clin Exp Dermatol 2014;39:228-230. 